Ann. Biol. anim. Bioch. Biophys., 1977, 17 (6), 987-990.

\title{
Observations on the motility and fertilizing ability of ram epididymal spermatozoa
}

\author{
par Suzanne FOURNIER-DELPECH, G. COLAS, M. COUROT, R. ORTAVANT \\ Station de Physiologie de la Reproduction, I. N. R. A. \\ Nouzilly 37380 Monnaie, France.
}

Summary. Fertilizing ability of epididymal ram spermatozoa was determined after intra utérine insemination of 47 ewes ; the fertility profile obtained was similar to the one established on rodents and boar. The middle corpus has an essential role in the development of the motility and fertilizing capacity of epididymal spermatozoa.

The fertilizing ability of epididymal spermatozoa and its endocrine control have been studied in rodents (Bedford, 1975 ; Orgebin-Crist, Danzo and Davies, 1975) ; fertilizing ability first appears in spermatozoa from the corpus epididymis. In the sow, pregnancies have been obtained after insemination of boar epididymal spermatozoa (Holtz and Smidt, 1976 ; Hunter, Smidt and Henfrey, 1976). Fertilizing ability in this species also first appeared in spermatozoa from the corpus epididymis. There is no data available on the development of fertilizing ability of ram spermatozoa during transit through the epididymis. It is known, however, that the permeability of the spermatozoon membrane is modified in the corpus (Ortavant, 1953). This maturation process might coincide with the appearance of fertilizing ability. We therefore undertook a physiological study of the maturation of ram epididymal spermatozoa by intrauterine insemination of ewes at induced ovulation during the breeding season.

\section{Materials and methods.}

Ovulation was induced in forty-seven 2-3-year old nulliparous lle-de-France ewes (Colas, 1975). 57 hours \pm 1 after PMSG injection, they were inseminated into the uterine horn by laparotomy under fluothane ancesthesia. Epididymides from 6 adult lle-de-France rams were subdivided into distal caput, middle and distal corpus and proximal and distal cauda. Sperm suspensions were prepared by maceration of epididymal tubules in a solution of skimmed milk (Colas, 1975);200 $\mu \mathrm{l}$ of a suspension of epididymal spermatozoa $\left(100 \times 10^{6} \mathrm{spz} / \mathrm{ml}\right)$ were introduced into both uterine horns at $1 \mathrm{~cm}$ from the uterotubal junction, and the ewes were inseminated. No more than 3 hrs elapsed between slaughter and insemination. 
The percentage of cells with progressive motility at $+38^{\circ} \mathrm{C}$ after dilution and the percentage of eosin-stained forms (Ortavant ef al., 1953) were estimated at the beginning and end of each series of inseminations ( 2 or 3 ewes), which were carried out in 3 or 4 replicates.

The number of ovulations was observed at the time of insemination. Pregnancy was estimated by radioimmunoassay of plasma progesterone at day 18 (Terqui and Thimonier, 1974). Fertilizing ability was expressed as a ratio of the number of pregnant ewes and lambing ewes to the number of ewes inseminated. Analyses were carried out using Fisher's analysis of variance and the corrected chi-square test.

\section{Results.}

\section{A. Ovarian paramefers and fertility.}

All the ewes were in the peri-ovulatory phase. There were more follicles on the right ovary than on the left one : $1.40 \pm 0.14$ ovulated or $1.46 \pm 0.15$ preovulatory follicles versus $0.66 \pm 0.16$ ovulated or $0.731 \pm 0.14$ preovulatory follicles, respectively $(P<0.001)$. The pregnancy rate of ewes with either preovulatory or ovulated follicles was the same after insemination of fertile spermatozod : 12 pregnancies/15 ewes inseminated prior to ovulation, 15 pregnancies/15 ewes inseminated after ovulation. The difference was not significant.

\section{B. Motility and morphology of epididymal spermatozoa.}

Spermatozoa from the distal caput show a light pendular movement of the tail, too slight to move the head of the cell. The amplitude of this movement sharply increased in spermatozoa from the middle corpus, giving the cells progressive motility. The percentage of motile spermatozoa progressively increased along the length of the epididymis : 1 in the distal caput, 5 in the middle corpus, $56 \pm 9$ in the distal corpus, $66 \pm 5$ in the proximal cauda and $83 \pm 4$ in the distal cauda. The difference between the distal corpus and the distal cauda was significant $(P<0.02)$.

The proportion of stained forms was elevated in the distal corpus (42 \pm 5 p. 100) but decreased in the distal cauda (14 \pm 3 p. 100). The number of abnormal spermatozoa (decapitated and distal droplets) was less than 5 p. 100.

\section{Fertilizing capacity of epididymal spermatozoa.}

1. The pregnancy test at day 18 showed that the fertilizing ability was zero for spermatozod from the distal caput $(0 / 8)$, very low for those from the middle corpus $(1 / 8)$, higher for those from the distal corpus $(7 / 8)$ and maintained in those from the proximal cauda (8/8) and the distal cauda (12/15).

2. Embryonic mortality was observed only after insemination with spermatozoa from the epididymal corpus: $1 / 1$ and 2/7 ewes pregnant at 18 days after insemination with spermatozoa from the middle and distal corpus did not lamb, but the level of embryonic mortality was $0 / 8$ and $0 / 12$ in the ewes inseminated with spermatozoa from the proximal and distal cauda of the epididymis, respectively. 


\section{Discussion.}

As in rodents (Bedford, 1975 ; Orgebin-Crist, Danzo and Davies, 1975) and in the boar (Holtz and Smidt, 1976 ; Hunter, Holtz and Henfrey, 1976), ram spermatozoon fertilizing ability and motility develop in the disial corpus epididymis ; fertilizing ability was assessed by the number of pregnancies at 18 days post-insemination (Terqui and Thimonier, 1974). But the lambing results (only 5 ewes lambing/ 8 ewes pregnant) suggest that some embryonic mortality occurred after fertilization with spermatozoa from the corpus epididymis ; this was not observed with spermatozod from the cauda epididymis (20 lambing ewes/20 pregnant ewes).

The significant increase in sperm motility could explain the evolution of fertilizing ability ; the number of motile spermatozoa from the distal corpus $\left(11.2 \times 10^{6} /\right.$ horn) was probably sufficient to achieve gestation. On the other hand, the introduction of $20 \times 10^{6}$ total spermatozoa/horn was probably insufficient to obtain gestation using spermatozoa from the distal caput and middle corpus because of the low number of motile elements $\left(0.2 \times 10^{6}\right.$ and $1.0 \times 10^{6}$, respectively) and because spermatozoa progress though the uterotubal junction by their own motility (Dauzier, 1958).

These maturation processes occurring in the middle corpus indicate rapid development since spermatozoa pass through the corpus in less than one day (Amir and Ortavant, 1968).

In conclusion, the fertility profile of ram epididymal spermatozoa has been defined ; it is similar to that obtained in rodents and in the boar.

Reçu en mars 1977.

Accepté en mai 1977.

Résumé. L'apparition de la fécondance du sperme épididymaire du bélier a été étudiée par insémination intra-utérine sous laparotomie chez 47 brebis dont l'ovulation a été induite. Il existe un processus de maturation épididymaire analogue à celui qui esi connu chez les rongeurs et le porc. Le corps moyen de l'épididyme joue un rôle essentiel dans le développement de la motibilité et dans celui de la fécondance. Il semble que les spermatozoïdes du corps de l'épididyme, bien qu'ayant acquis leur fécondance, entraînent une forte mortalité embryonnaire non observée avec les spermatozoïdes provenant de la queve. Ces résultats sont discutés en faisant référence à la motilité.

\section{References}

AMIR D., ORTAVANT R., 1968. Influence de la fréquence des collectes sur la durée du transit des spermatozoïdes dans le canal épididymaire du bélier. Ann. Biol. anim. Bioch. Biophys., 8, 195-207.

BEDFORD J. M., 1975. Maturation, transport and fate of spermatozod in the epididymis, 303-317. In : HAMILTON D. W., GREEP R. O. Hondbook of Physiology, sect. 7, Endocrinology Vol. V, Ann. Physiol., Soc.

COLAS G., BRICE G., GUERIN G., 1974. Acquisitions récentes en matière d'insémination artificielle ovine. Bull. Techn. Inf., 294, 765-769.

COLAS G., 1975. The use of progestagen SC 9880 as an aid for artificial insemination in ewes. Ann. Biol. anim. Bioch. Biophys., 15, 317-327.

DAUZIER L., 1958. Physiologie du déplacement des spermatozoïdes dans les voies génitales femelles de la brebis ef de la vache. Ann. Zootech., 7, 281-351. 
HOLTZ W., SMIDT D., 1976.The fertilizing capacity of epididymal spermatozoa in the pig. J. Reprod. Fert., 46, 227-229.

HUNTER R. H. F., HOLTZ W., HENFREY P. J., 1976. Epididymal function in the boar in relation to the fertilizing ability of spermatozoa. J. Reprod. Fert., 46, 463-466.

ORGEBIN-CRIST M. C., DANZO B., DAVIED J., 1975. Endocrine control of the development and maintenance of sperm fertilizing ability in the epididymis, 319-338. in : HAMILTON D. W. GREEP R. O. Handbook of Physiology, sect. 7, Endocrinology Vol. V, Ann. Physiol. Soc.

ORTAVANT R., DUPONT S., PAUTHE H., ROUSSEL G., 1953. Contribution à l'étude de la différenciation des spermatozoïdes morts et des spermatozoïdes vivants dans le sperme de taureau. Ann. Zootech., 2, 1-8.

ORTAVANT R., 1953. Existence d'une phase critique dans la maturation épididymaire des spermatozoïdes de bélier et de taureau. C. R. Soc. Biol., 147, 1952-1956.

TERQUI M., THIMONIER J., 1974. Nouvelle méthode radioimmunologique rapide pour l'estimation du niveau de progestérone plasmatique. Application pour le diagnostic précoce de la gestation chez la brebis et chez la chèvre. C. R. Acad. Sc., Paris série D, 279, 1109-1112. 